\title{
Acyclic retinoid, a novel synthetic retinoid, induces growth inhibition, apoptosis, and changes in mRNA expression of cell cycle- and differentiation-related molecules in human colon carcinoma cells
}

\author{
MASUMI SUZUI ${ }^{1,3}$, NAO SUNAGAWA ${ }^{1}$, ITARU CHIBA ${ }^{1}$, HISATAKA MORIWAKI ${ }^{2}$ and NAOKI YOSHIMI ${ }^{1}$ \\ ${ }^{1}$ Tumor Pathology Divison, University of the Ryukyus Faculty of Medicine, 207 Uehara Nishihara-cho, Okinawa 903-0215; \\ ${ }^{2}$ Department of Internal Medicine, Gifu University School of Medicine, 1-1 Yanagido, Gifu 501-1194, Japan
}

Received November 29, 2005; Accepted January 9, 2006

\begin{abstract}
Acyclic retinoid (ACR), a novel synthetic retinoid, has been demonstrated by us to inhibit the in vitro growth of human hepatoma cells, and this effect was associated with modification of cell cycle control molecules, suggesting that this agent may be useful in the chemoprevention and therapy of various types of malignancies. However, whether or not ACR exerts anticancer activities on human colon carcinoma cells has not yet been elucidated. The purpose of this study was to examine the inhibitory effects of ACR in human colon carcinoma cells and to characterize the molecular mechanism of action of this agent. ACR inhibited the growth of the HCT116 and SW480 human colon carcinoma cell lines with $\mathrm{IC}_{50}$ values of about 30 and $60 \mu \mathrm{M}$, respectively. ACR also induced G1-phase cell cycle arrest and apoptosis in these cell lines. When the HCT116 cells were treated with 5-25 $\mu \mathrm{M}$ ACR, there was a marked decrease in the cellular levels of cyclin D1 mRNA and an approximate 2.5- to 3-fold increase in those of $\mathrm{p} 21^{\mathrm{CIP} 1} \mathrm{mRNA}$, and this induction occurred via a p53-independent mechanism. Furthermore, ACR induced a dose-dependent mRNA elevation of differentiation markers at concentrations of ACR that affect the levels of expression of $\mathrm{p} 21^{\mathrm{CIP} 1}$. These novel results suggest that ACR inhibits cell proliferation by inducing G1 arrest and apoptosis and that cyclin D1 and $\mathrm{p} 21^{\mathrm{CIP} 1}$ play critical roles in the molecular mechanisms of growth inhibition and differentiation induced by ACR. Collectively, these findings provide further evidence that ACR may be a potential agent for the chemoprevention and therapy of human colon cancer.
\end{abstract}

Correspondence to: Dr Masumi Suzui, Tumor Pathology Division, Faculty of Medicine, University of the Ryukyus, 207 Uehara Nishihara-cho, Okinawa 903-0215, Japan

E-mail: suzui@med.u-ryukyu.ac.jp

Key words: acyclic retinoid, colon cancer, prevention, differentiation, $\mathrm{p} 21^{\mathrm{CIP} 1}$

\section{Introduction}

Retinoids are a group of structural and functional analogues of vitamin A that exhibit a variety of effects on cell proliferation, development, and pattern formation during development (1). In the last ten years, there has been considerable interest in the use of retinoids for the treatment and prevention of cancer (2). Indeed, much evidence has demonstrated that all-transretinoic acid (ATRA, tretinoin), 13-cis-retinoic acid (13-cisRA, isotretinoin), 9-cis-retinoic acid (9-cis-RA, alitretinoin, panretin), and $N$-(4-hydroxyphenyl)retinamide (4-HPR, fenretinide) have been clinically used and tested as therapeutic or chemopreventive agents for leukoplakia and various types of malignancies (2). Novel synthetic retinoids that bind selectively to retinoid X receptors (RXRs) are termed rexinoids (3) and include LGD1069 (targretin, bexarotene) and LG100268. These drugs have recently been shown to be promising as chemotherapeutic or chemopreventive agents for patients who suffer from advanced non-small-cell lung carcinoma (NSCLC) and breast carcinoma at high risk $(4,5)$. The novel synthetic retinoid, named acyclic retinoid (ACR), has been demonstrated to prevent the recurrence of hepatoma after surgical resection of primary tumors (6-8). In these studies, ACR did not cause the typical adverse side effects seen with conventional retinoids $(6,7)$. This unique agent was reported to inhibit carcinogeninduced rat hepatocarcinogenesis and this inhibition occurred through suppression of transforming growth factor $\alpha(\mathrm{TGF} \alpha)$ expression and cell proliferation (9). ACR was also shown to induce differentiation, growth inhibition, and apoptosis via a down-regulation of $\mathrm{TGF}_{\alpha}$ in human hepatoma cell lines (10-12). In addition, large-scale clinical trials objecting second primary hepatoma cases are being conducted to elucidate its efficacy in advanced diseases.

Gene amplification and/or protein overexpression of cyclin D1 occur in a variety of human carcinomas, including colon carcinoma (13-16), indicating that cyclin D1 plays a critical role in the development of human colon carcinogenesis. Furthermore, an increased expression of the cyclin D1 protein was found in precursor lesions of the human colon and esophagus $(17,18)$ and also in aberrant crypt foci (ACF) of 
the rat colon $(19,20)$. In addition, cyclin D1 gene amplification and protein overexpression have recently been found to be associated with a poor prognosis in patients with colon carcinoma (15). These findings suggest that cyclin D1 may be a useful biomarker and a potential target for prevention and therapy of colon carcinoma. In recent studies, we found that the growth inhibitory effect by ACR is associated with induction of $\mathrm{p} 21^{\mathrm{CIP} 1}$ and inhibition of expression of cyclin D1 in human hepatoma, head and neck squamous cell carcinoma, and esophageal carcinoma cells $(21,22)$. We also found that ACR induces transcriptional activation of retinoic acid receptor $\beta(\mathrm{RAR} \beta)$ and $\mathrm{p} 21^{\mathrm{CIP} 1}$ in several types of human carcinoma cells $(22,23)$. These novel effects of ACR suggest that this agent may be useful in the chemoprevention and therapy of various types of human malignancies.

Despite recent clinical advances that have been tested in chemotherapeutic treatment (24), colon carcinoma remains a major issue due to its incidence, morbidity, and mortality $(25,26)$. In addition to development of a mechanistic understanding of how this carcinoma occurs, grows, and spreads, there is also an urgent need to develop more effective and less toxic drugs for its prevention and treatment. However, whether or not ACR exerts anticancer activity on human colon carcinoma cells has not yet been elucidated. Therefore, in the present study, we used a cell culture system to investigate the range of anticancer activity of ACR on human colon carcinoma cells and to obtain insights into its molecular mechanism of action, and we examined the effects of ACR on cell proliferation, cell cycle progression, differentiation, apoptosis, and the levels of expression of several cell cycle control molecules.

\section{Materials and methods}

Chemicals. ACR (NIK333) (Fig. 1) was supplied by Nikken Chemicals Co. Ltd. (Tokyo, Japan).

Cell lines and cell culture. The HCT116 and SW480 human colon carcinoma cell lines were generously provided by Dr I. Bernard Weinstein (Columbia University College of Physicians and Surgeons, NY) and were maintained in Dulbecco's modified Eagle's medium (DMEM) (Invitrogen Life Technologies, Inc., Rockville, MD) supplemented with $10 \%$ (v/v) heat-inactivated fetal bovine serum (FBS) (Invitrogen) in an incubator with humidified air at $37^{\circ} \mathrm{C}$ with $5 \% \mathrm{CO}_{2}$.

Cell proliferation assay. Cell proliferation assay was performed as recently described (27). To determine the cell viability, exponentially dividing $2 \times 10^{4}$ cells were plated into 6-well/ 35-mm diameter culture dishes and treated with the indicated concentrations of ACR in DMEM plus 10\% FBS for $48 \mathrm{~h}$. Each concentration of ACR was tested in triplicate. After trypsinization, the number of attached viable cells was counted using a Coulter Counter (Beckman Coulter Co., Fullerton, CA). As an untreated solvent control, cells were treated with dimethyl sulfoxide (DMSO) (Sigma), at a final concentration of $<0.1 \%$. The results were expressed as percentage of growth, with $100 \%$ representing control cells treated with DMSO alone.
Flow cytometry analysis. Flow cytometry analysis was performed as described in a recent report (27). HCT116 cells were plated onto $10-\mathrm{cm}$ diameter culture dishes $\left(5 \times 10^{4}\right.$ cells/ dish) in DMEM plus 10\% FBS and cultured to yield 50-60\% confluence. Cells were then treated with DMSO $(<0.1 \%)$ or increasing concentrations $(10-90 \mu \mathrm{M})$ of ACR. After treatment of cells for $48 \mathrm{~h}$, both adherent and floating cells were collected, fixed with $70 \%$ ethanol, centrifuged, resuspended in $400 \mu \mathrm{l}$ of PBS containing $2 \mathrm{mg} / \mathrm{ml} \mathrm{RNase} \mathrm{(Sigma),} \mathrm{and}$ stained with $400 \mu \mathrm{l}$ of $0.1 \mathrm{mg} / \mathrm{ml}$ propidium iodide (PI) (Sigma). The cell suspension was filtered through a $60-\mu \mathrm{m}$ nylon filter (Ikemoto Scientific Technology Co., Ltd., Tokyo). Samples of 10,000-20,000 cells were then analyzed for DNA histograms and cell cycle phase distributions by flow cytometry using a FACScalibur instrument (Becton-Dickinson, Franklin Lakes, NJ), and the data were analyzed using CellQuest software (Becton-Dickinson), as recently described (27). The percentage of cells that had undergone apoptosis was also determined as the sub-G1 fraction of at least 10,000 cells using the above-described PI staining method. All experiments were conducted in duplicate and yielded similar results. In cell cultures, apoptosis was also detected by observing DNA fragmentation on agarose gel electrophoresis (27). In brief, after treatment of cells with the indicated concentrations of ACR for $48 \mathrm{~h}$, both adherent and floating cells were harvested, centrifuged, and washed twice with phosphate-buffered saline (PBS). The cell pellet was then homogenized in $400 \mu 1$ of $50 \mathrm{mM}$ SEDTA $(0.1 \mathrm{M} \mathrm{NaCl}$ and $50 \mathrm{mM}$ EDTA). After supplementation of $1 \%$ sodium dodecyl sulfate (SDS), the homogenate was digested with proteinase $\mathrm{K}$ and then extracted twice with phenol and chloroform, and DNA was precipitated with ethanol. After RNase treatment, DNA fragmentation was visualized by agarose gel electrophoresis and ethidium bromide staining.

Reverse transcription-PCR (RT-PCR) analysis. These assays were performed using established procedures (23). Total RNA was isolated from frozen cells using a TRIzol reagent (Invitrogen Life Technologies) as recommended by the manufacturer. cDNA was amplified from total RNA $(1.0 \mu \mathrm{g})$ using a SuperScript One-Step RT-PCR system (Invitrogen Life Technologies). PCR was conducted for 22-40 cycles in a GeneAmp PCR system 9700 (Applied Biosystems, Foster City, CA). The primers (23) used for amplification were as follows: cyclin D1-specific primer set, CD1F (5'-CTG GCC ATG AAC TAC CTG GA-3') and CD1R (5'-GTC ACA CTT GAT CAC TCT GG-3'); p21 ${ }^{\mathrm{CIP} 1}$-specific primer set, C1F (5'-CTC AGA GGA GGC GCC ATG TCA-3') and C2R (5'-GCC GTT TTC GAC CCT GAG AGT-3'); p27 ${ }^{\mathrm{KIP} 1}$ specific primer set, K2F (5'-GCT CAC GGC TCT GCG ACT CC-3') and K1R (5'-GGG CTC CCG TTA GAC ACT CG-3'); p53-specific primer set, P1F (5'-TCA GAT CCT AGC GTC GAG CCC-3') and P2R (5'-GGG TGT GGA ATC AAC CCA CAG-3'); ALP-specific primer set, ALPF1 (5'-GCT CTC CCT GGG CGT CAT CC-3') and ALPR2 (5'-TGA CTT TCC TGC TTG CTT GG-3'), and E-cadherin-specific primer set, CDHF2 (3'-CTG GCT TTG ACG CCG AGA GC-3') and CDHR1 (5'-AGT TGG GAA ATG TGA GCA AT-3'). B-actin-specific PCR products for the same RNA samples were simultaneously amplified and served as internal 
A<smiles>CC(C)=CC=CC=C(C)CCC=CC(=O)O</smiles>

B<smiles>C=C(C)/C=C/C=C(C)/C=C/C1=C(C)CCCC1(C)C</smiles>

C

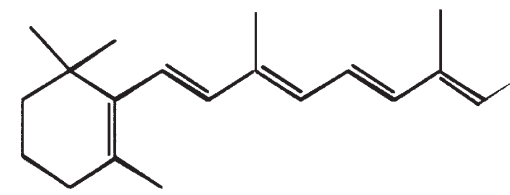

$\mathrm{CH} 2 \mathrm{OH}$

Figure 1. Chemical structures of (2E, 4E, 6E, 10E)-3, 7, 11, 15-tetramethyl2, 4, 6, 10, 14,-hexadecapentaenoic acid (acyclic retinoid, ACR, NIK333) (A), all-trans retinoic acid (ATRA) (B), and vitamin A (C).

controls. Primers FBA (5'-CCA GGC ACC AGG GCG TGA TG-3') and RBA (5'-CGG CCA GCC AGG TCC AGA CG-3') were used for amplification of $\beta$-actin. Each amplification cycle consisted of $0.5 \mathrm{~min}$ at $94^{\circ} \mathrm{C}$ for denaturing, $0.5 \mathrm{~min}$ at $55^{\circ} \mathrm{C}$ for primer annealing, and $1 \mathrm{~min}$ at $72^{\circ} \mathrm{C}$ for extension. In all of the amplification procedures, we included RT-free control assays consisting of the amplification cocktail, the RNA sample and distilled water in place of RT, to check for possible contamination of the RNA samples with DNA. After PCR amplification, the fragments were analyzed by agarose gel electrophoresis and stained with ethidium bromide. The results were confirmed by repeated experiments.

\section{Results}

ACR inhibits the growth and induces G1-phase cell cycle arrest and apoptosis in human colon carcinoma cells. In cell proliferation assays, we treated HCT116 and SW480 cells with DMSO (control) or increasing dose levels (0.1-200 $\mu \mathrm{M})$ of ACR. In these cell lines, ACR caused a marked and dosedependent growth inhibition with $\mathrm{IC}_{50}$ values of approximately 30 and $60 \mu \mathrm{M}$, respectively, when cells were grown in DMEM plus $10 \%$ FBS for $48 \mathrm{~h}$ (Fig. 2). Because of the ACR's growth inhibitory effect, we further examined the effects of ACR on cell cycle progression in the HCT116 cell line. When HCT116 cells were treated with 10-60 $\mu \mathrm{M} \mathrm{ACR}$ for $48 \mathrm{~h}$, there was a marked increase ( $\sim 9-18 \%)$ of cells in the G1 phase of the cell cycle, with a concomitant decrease of cells in the S and G2-M phases (Fig. 3A-D). When these cells were treated with higher concentrations $(>60 \mu \mathrm{M})$ of ACR for $>48 \mathrm{~h}$, they began to detach from the bottom of the culture plate and displayed evidence of apoptosis as detected in a sub-G1 fraction ( $5 \%$ and 30\%; Fig. 3D and E respectively). A DNA ladder was seen in a sample treated with $90 \mu \mathrm{M}$ ACR on agarose gel electrophoresis (Fig. 3F). Similar results were also obtained

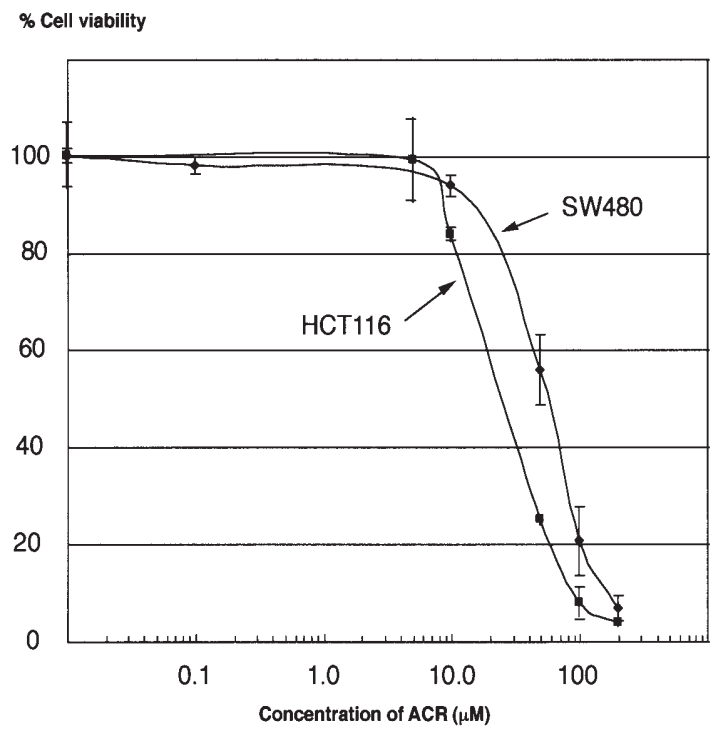

Figure 2. Inhibition of cell growth by ACR in human colon carcinoma cell lines. Cells were treated with the indicated concentrations of ACR for $48 \mathrm{~h}$ in DMEM containing $10 \%$ FBS. Results were expressed as a percentage of growth, with $100 \%$ representing control cells treated with DMSO alone. Each concentration of ACR was examined in triplicate and gave similar results.

with the SW480 cell line (data not shown). These results suggest that ACR inhibits the growth of human colon carcinoma cells in a dose-dependent manner and induces G1 cell cycle arrest and apoptosis.

ACR causes a marked decrease in the cellular levels of cyclin DI mRNA and a marked increase in those of $p 21^{C I P 1}$ $m R N A$. In the above studies, we found that ACR arrests colon carcinoma cells in the G1 phase of the cell cycle after $48 \mathrm{~h}$ of treatment. Thus, we performed RT-PCT analysis to determine whether treatment of these cells with ACR affects the level of expression of cyclin D1 mRNA. We treated HCT116 cells with increasing doses $(1-25 \mu \mathrm{M})$ of ACR in DMEM containing $10 \%$ FBS. We then isolated RNA at $48 \mathrm{~h}$ after the addition of the drug. To quantify the expression levels of mRNA, PCR products were generated during both plateau and log-phase reactions by conducting 22-40 cycles of PCR as described in a recent study (23). Using this approach, these products have been shown to reflect corresponding levels of mRNA by Northern blot assays $(21,23)$. There was a marked decrease in the cyclin D1 intensity in samples treated with $25 \mu \mathrm{M}$ ACR and also a decrease in samples treated with 1 and $5 \mu \mathrm{M}$ ACR, when compared to that of samples treated with DMSO alone (Fig. 4A). ACR also caused a 2.5- to 3-fold increase in the p21 $1^{\mathrm{CIP} 1}$ band intensity in samples treated with 5 and $25 \mu \mathrm{M}$ ACR. However, RT-PCR assays for p27 $7^{\mathrm{KIP} 1}$ mRNA displayed no change in cellular levels of mRNA in samples treated with 1-25 $\mu \mathrm{M}$ ACR (Fig. 4A). These results suggest that, at doses ranging from 1 to $25 \mu \mathrm{M}$, ACR causes a decrease in the level of expression of cyclin D1 mRNA. Combined with the results of the flow cytometry analysis, this suggests that ACR causes G1 cell cycle arrest by inhibiting the expression of cyclin D1 mRNA and inducing p $21^{\mathrm{CIP1}} \mathrm{mRNA}$ and thereby causes growth inhibition of human colon carcinoma cells. 

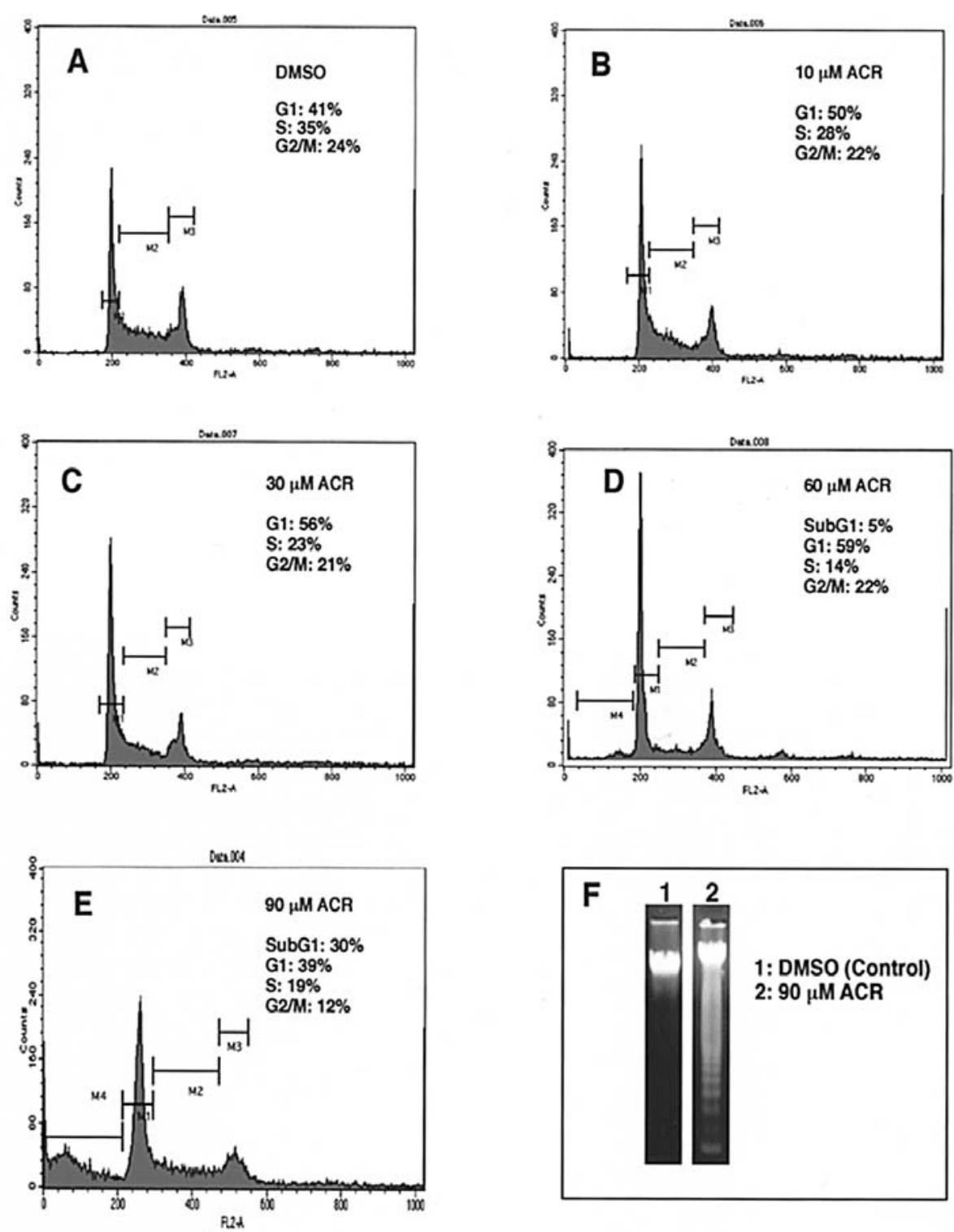

Figure 3. Effects of ACR on cell cycle progression and apoptosis. HCT116 cells were treated with DMSO (A) or 10-90 $\mu$ M ACR (B-E) for $48 \mathrm{~h}$ (A-D) or $72 \mathrm{~h}$ (E) in DMEM plus 10\% FBS. The data indicate the percentage of cells in the indicated phase of the cell cycle. Note evidence of apoptosis by an increase in the sub-G1 population of cells (D and E). DNA fragmentation was seen in agarose gel electrophoresis (F). DNA was extracted from cells treated with DMSO or $90 \mu \mathrm{M}$ ACR.

ACR induces dose-dependent mRNA elevation of differentiation markers in human colon carcinoma cells. Alkaline phosphatase (ALP) and E-cadherin are well-established indicators of cell differentiation $(28,29)$. Cell differentiation is a major issue of invasion and metastasis since poorly differentiated carcinoma cells may avoid host defenses. We therefore examined whether ACR induces mRNA expression of these terminal differentiation markers in the HCT116 cell line. The cells were treated with different concentrations $(5$ and $25 \mu \mathrm{M}$ ) of ACR for $48 \mathrm{~h}$ in DMEM/10\% FBS. There was a 1.5-3.8-fold increase of ALP mRNA expression, which occurred in a dose-dependent manner (Fig. 4B). Another indicator of cell differentiation in human colon carcinoma cells, E-cadherin, was also induced by approximately 2.4- to 3.8-fold in the cellular level of mRNA in a dose-dependent fashion (Fig. 4B). These results suggest that cell differentiation is induced by concentrations of ACR that affect the levels of expression of $\mathrm{p} 21^{\mathrm{CIP} 1} \mathrm{mRNA}$.

\section{Discussion}

ACR is currently being evaluated in extensive clinical therapy trials objecting second primary hepatoma as a potential cancer preventive agent (6-8). This drug has also been shown to have anticancer activities in cell culture experiments and animal hepatocarcinogenesis models $(10,30,31)$. In recent studies, we found that ACR inhibits in vitro growth of human hepatoma, HNSCC, and esophageal carcinoma cell lines, and this effect was associated with decreased expression of cyclin D1 and transcriptional activation of p21 CIP1 (21-23). These findings, combined with previous in vitro and clinical studies with ACR, suggest that this agent may be useful in the chemoprevention and therapy of hepatoma and, possibly, other human malignancies. Therefore, we conducted the present study to further characterize the anticancer properties of ACR on human colon carcinoma cells. In the initial studies, we found that ACR exerted a marked and dose-dependent inhibition on 
A
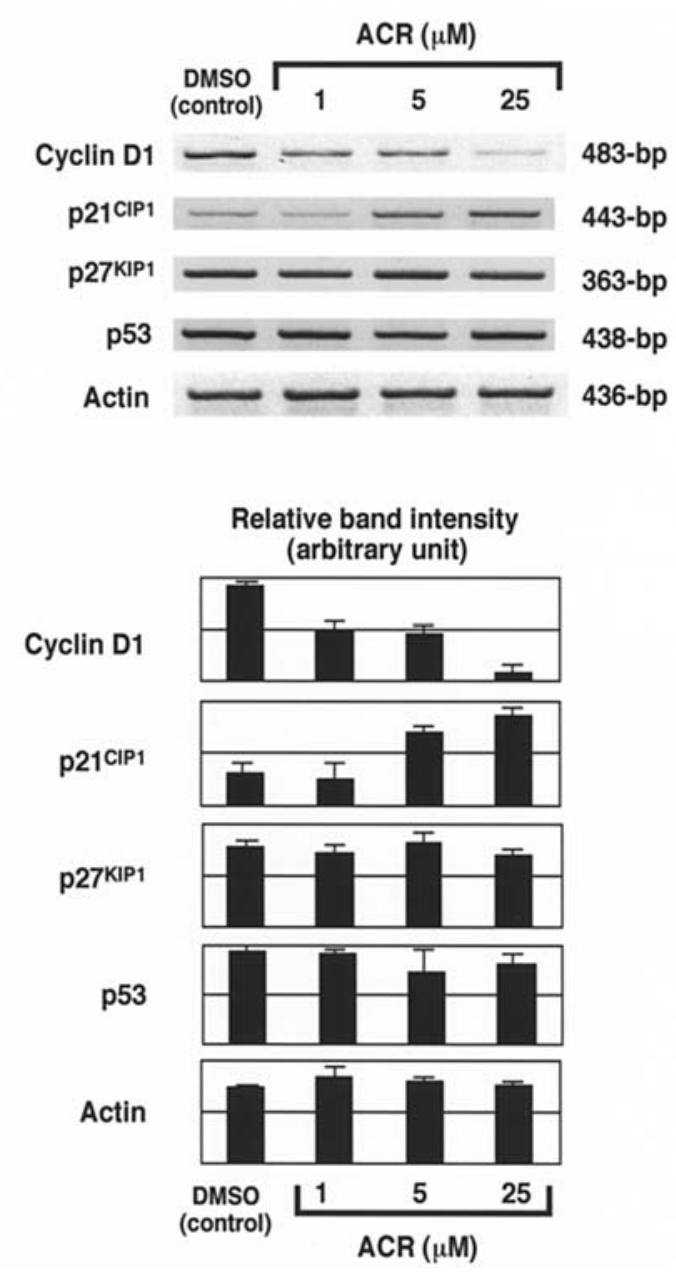

the growth of the HCT116 and SW480 human colon carcinoma cell lines, with $\mathrm{IC}_{50}$ values of approximately 30 and $60 \mu \mathrm{M}$, respectively, when the cells were grown in DMEM plus $10 \%$ FBS. These values are similar to those of our previous studies demonstrating 10-40 $\mu \mathrm{M} \mathrm{IC}_{50}$ in human hepatoma, esophageal SCC or HNSCC cell lines $(21,22)$. Previous studies using ATRA, 4-HPR or novel synthetic retinoid derivative 4-amino2-(butyrylamino)phenyl-(2E,4E,6E,8E)-3,7-dimethyl-9-(2,6,6trimethyl-1-cyclohexenyl)-2,4,6,8-nonatetraenoate (ABPN or CBG41) evaluated concentrations that show significant growth inhibition in the range of approximately $0.6-20 \mu \mathrm{M}$, when HCT116, HT29, or DLD-1 human colon carcinoma cells were grown in culture conditions similar to those in our studies $(32,33)$. These retinoids also display growth inhibitory activity in other types of human carcinoma cell lines (33). Collectively, these data demonstrate the broad range of in vitro anticancer properties of retinoids including ACR in a spectrum of human carcinoma cell lines.

To further characterize the effects of ACR on cell cycle progression and apoptosis, we examined whether ACR arrests cells in specific phases of the cell cycle and induces apoptosis using flow cytometry analysis. In the present study, we found that ACR induces G1 arrest and apoptosis in the HCT116 cell line, after treatment of cells with 10-60 $\mu \mathrm{M}$ and $>60 \mu \mathrm{M} \mathrm{ACR}$, respectively, for $48 \mathrm{~h}$ (Fig. 3D-F). Similar observations were
B

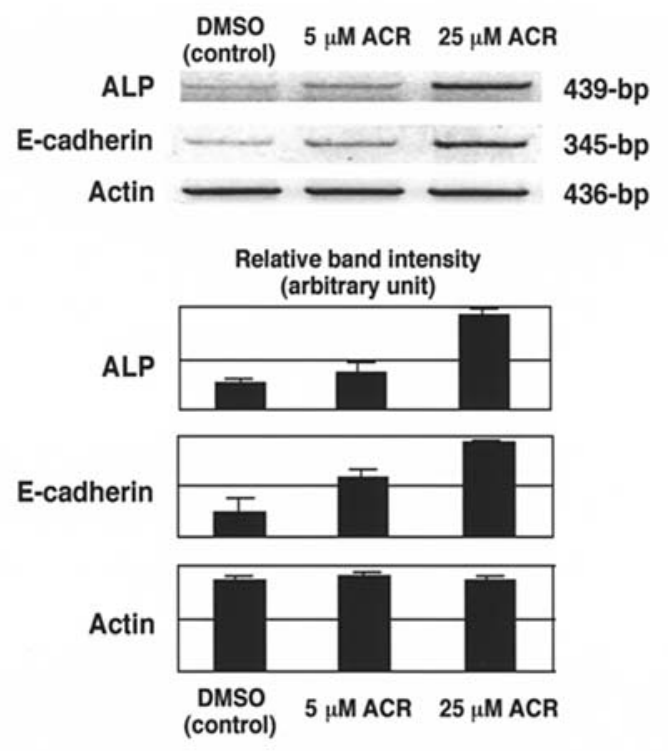

Figure 4. Effects of ACR on mRNA expression of cell cycle control molecules (A) and differentiation markers (B). Upper panels, representative results of RT-PCR assays. HCT116 cells were treated with DMSO (control) or the indicated concentrations of ACR for $48 \mathrm{~h}$ in DMEM containing $10 \%$ FBS. RNA samples were then analyzed by RT-PCR using the pairs of primers shown in Materials and methods. Actin was used as an internal control. The results were confirmed by repeated experiments. Lower panels, densitometric analysis representing relative band intensity in each RNA sample. The results are the means \pm SD from repeated experiments. Note dose-dependent decrease and increase in band intensity of cyclin D1 and p2 $1^{\mathrm{CIP} 1}$, respectively (A) and elevated mRNA expression of ALP and Ecadherin (B).

also found in our previous work using the human hepatoma cell line (21). These findings suggested that the antiproliferative effect of ACR is due to G1-phase arrest and apoptotic cell death. Therefore, we then examined ACR's molecular mechanism of action in the G1 progression of the cell cycle. Cyclin D1 complexes with cyclin-dependent kinase (cdk)-4 and cdk6 and regulates transition from the G1 phase to the S phase (16). The activities of these cyclin D1/cdk complexes are negatively regulated by the cdk inhibitors (CDKIs) including $\mathrm{p} 21^{\mathrm{CIP} 1}$ and $\mathrm{p} 27^{\mathrm{KIP} 1}$ (16). RT-PCR analysis indicated that the ACR-treated HCT116 cells displayed a marked decrease in the levels of expression of cyclin D1 mRNA and also a marked increase ( 2.5- to 3-fold) in those of p21 ${ }^{\mathrm{CIP} 1} \mathrm{mRNA}$ at $48 \mathrm{~h}$ after the addition of the compound, and the induction of p21 ${ }^{\mathrm{CIP1}}$ mRNA was not associated with the cellular levels of p53 mRNA (Fig. 4), suggesting that ACR induces p21 ${ }^{\mathrm{CIP} 1}$ expression via a p53-independent mechanism in the HCT116 cell line that carries wild-type p53 (34). We also found that ACR inhibits cyclin D1 promoter activity in a dose-dependent manner (unpublished data). These findings suggest that the marked decrease in cyclin D1 may cooperate with the induction of $\mathrm{p} 21^{\mathrm{CIP} 1}$ to arrest colon carcinoma cells in G1-phase and thereby further contribute to ACR-induced growth inhibition.

$\mathrm{p} 21^{\mathrm{CIP} 1}$ is a primary response gene in the induction of differentiation of HL60 human leukemia cells by ATRA 
(35). Several inducers of myeloid cell differentiation also upregulate $\mathrm{p} 21^{\mathrm{CIP} 1}$ expression $(35,36)$. These include $12-O$ tetradecanoyl phorbol-13-acetate (TPA), okadaic acid, sodium butyrate, DMSO, 1,25-dihydroxyvitam D3 (vit D3), and retinoids, suggesting that the $\mathrm{p} 21^{\mathrm{CIP1}}$ promoter contains multiple response elements involved in cell cycle arrest, growth inhibition, and differentiation. In the present study, we found that ACR causes a marked increase in the levels of mRNA expression of the differentiation markers, ALP and E-cadherin, of human colon carcinoma cells. This induction occurred at concentrations that affect $\mathrm{p} 21^{\mathrm{CIP} 1} \mathrm{mRNA}$ expression. Therefore, ACR can induce differentiation in human colon carcinoma cells and this effect may be mediated, at least in part, through the induction of $\mathrm{p} 21^{\mathrm{CIP} 1}$. This speculation is consistent with evidence that ACR causes rapid induction of $\mathrm{p} 21^{\mathrm{CIP} 1}$ expression in HepG2 human hepatoma cells and that treatment of Huh7, Hep3B, and PLC/PRL/5 human hepatoma cell lines with ACR also induces expression of albumin mRNA, a differentiation marker in hepatoma cells (12). Carcinogenesis may occur via aberrant differentiation, and the differentiation status of cancer is a critical factor that determines the response to chemopreventive and/or therapeutic properties of agents (37). Therefore, the clinical application of ACR in inducing differentiation and in chemoprevention or therapy of human malignancies, including colon cancer, warrants further investigation.

A serious limitation in the clinical use of retinoid compounds in cancer prevention and therapy is their adverse side effects, particularly those caused by prolonged administration. Clinical studies with ACR have not revealed these adverse effects $(6,7)$. The existence of several mechanisms of action may contribute to the ACR's better tolerance and less adverse side effects. In fact, other than the inhibitory effect of ACR on cell cycle control molecules, the suppression of TGF $\alpha$ expression and the fibroblast growth factor (FGF) signaling pathway as a mechanism for ACR's chemopreventive effect has been suggested $(9,10,38)$, and microarray analysis has recently postulated that several differentially expressed genes are associated with drug tolerance (39). However, this issue warrants further study.

\section{Acknowledgements}

We thank Takahiro Shimizu for the excellent technical assistance. This study was supported by a Grant-in-Aid from the Ministry of Health, Labour, and Welfare of Japan, and the Ministry of Education, Culture, Sports, Science, and Technology of Japan.

\section{References}

1. Thaller $\mathrm{C}$ and Eichele G: Identification and spatial distribution of retinoids in the developing chick limb bud. Nature 327: 625-628, 1987.

2. Altucci $\mathrm{L}$ and Gronemeyer $\mathrm{H}$ : The promise of retinoids to fight against cancer. Nat Rev Cancer 1: 181-193, 2001.

3. Sporn MB and Suh N: Chemoprevention of cancer. Carcinogenesis 21: 525-530, 2000.

4. Edelman MJ, Smith R, Hausner P, Doyle LA, Kalra K, Kendall J, Bedor $\mathrm{M}$ and Bisaccia S: Phase II trial of the novel retinoid, bexarotene, and gemcitabine plus carboplatin in advanced nonsmall-cell lung cancer. J Clin Oncol 23: 5774-5778, 2005.
5. Suh N, Lamph WW, Glasebrook AL, Grese TA, Palkowitz AD, Williams CR, Risingsong R, Farris MR, Heyman RA and Sporn MB: Prevention and treatment of experimental breast cancer with the combination of a new selective estrogen receptor modulator, arzoxifene, and a new rexinoid, LG 100268. Clin Cancer Res 8: 3270-3275, 2002.

6. Muto Y, Moriwaki H, Ninomiya M, Adachi S, Saito A, Takasaki KT, Tanaka T, Tsurumi K, Okuno M, Tomita E, Nakamura T and Kojima T: Prevention of second primary tumors by an acyclic retinoid, polyprenoic acid, in patients with hepatocellular carcinoma. N Engl J Med 334: 1561-1567, 1996.

7. Muto Y, Moriwaki H and Saito A: Prevention of second primary tumors by an acyclic retinoid in patients with hepatocellular carcinoma. N Engl J Med 340: 1046-1047, 1999.

8. Takai K, Okun M, Yasuda I, Matsushima-Nishiwaki R, Uematsu T, Tsurumi H, Shiratori Y, Muto Y and Moriwaki H: Prevention of second primary tumors by an acyclic retinoid in patients with hepatocellular carcinoma. Updated analysis of the long-term follow-up data. Intervirology 48: 39-45, 2005.

9. Kagawa M, Sano T, Ishibashi N, Hashimoto M, Okuno M, Moriwaki H, Suzuki R, Kohno H and Tanaka T: An acyclic retinoid, NIK-333, inhibits N-diethylnitrosamine-induced rat hepatocarcinogenesis through suppression of TGF- $\alpha$ expression and cell proliferation. Carcinogenesis 25: 979-985, 2004.

10. Nakamura N, Shidoji Y, Moriwaki H and Muto Y: Apoptosis in human hepatoma cell line induced by 4,5-didehydrogeranylgeranoic acid (acyclic retinoid) via down-regulation of transforming growth factor- $\alpha$. Biochem Biophys Res Commun 219: 100-104, 1996.

11. Matsushima-Nishiwaki R, Okuno M, Takano Y, Kojima S, Friedman SL and Moriwaki H: Molecular mechanism for growth suppression of human hepatocellular carcinoma cells by acyclic retinoid. Carcinogenesis 24: 1353-1359, 2003.

12. Yamada Y, Shidoji Y, Fukutomi Y, Ishikawa T, Kaneko T, Nakagama H, Imawari M, Moriwaki H and Muto Y: Positive and negative regulations of albumin gene expression by retinoids in human hepatoma cell lines. Mol Carcinog 10: 151-158, 1994.

13. Mermelshtein A, Gerson A, Walfisch S, Delgado B, ShechterMaor G, Delgado J, Fich A and Gheber L: Expression of D-type cyclins in colon cancer and in cell lines from colon carcinomas. Br J Cancer 93: 338-345, 2005.

14. Bondi J, Husdal A, Bukholm G, Nesland JM, Bakka A and Bukholm IR: Expression and gene amplification of primary (A, $\mathrm{B} 1, \mathrm{D} 1, \mathrm{D} 3$, and E) and secondary $(\mathrm{C}$ and $\mathrm{H})$ cyclins in colon adenocarcinomas and correlation with patient outcome. J Clin Pathol 58: 509-514, 2005.

15. Bahnassy AA, Zekri AR, El-Houssini S, El-Shehaby AM, Mahmoud MR, Abdallah S and El-Serafi M: Cyclin A and cyclin D1 as significant prognostic markers in colorectal cancer patients. BMC Gastroenterol 4: 22, 2004.

16. Weinstein IB: Disorders in cell circuitry during multistage carcinogenesis: the role of homeostasis. Carcinogenesis 21: 857-864, 2000.

17. Arber N, Hibshoosh H, Moss SF, Sutter T, Zhang Y, Begg M, Wang S, Weinstein IB and Holt PR: Increased expression of cyclin D1 is an early event in multistage colorectal carcinogenesis. Gastroenterology 110: 669-674, 1996.

18. Arber N, Lightdale C, Rotterdam H, Han KH, Sgambato A, Yap E, Ahsan H, Finegold J, Stevens PD, Green PH, Hibshoosh H, Neugut AI, Holt PR and Weinstein IB: Increased expression of the cyclin D1 gene in Barrett's esophagus. Cancer Epidemiol Biomarkers Prev 5: 457-459, 1996.

19. Otori K, Sugiyama K, Fukushima S and Esumi H: Expression of the cyclin D1 gene in rat colorectal aberrant crypt foci and tumors induced by azoxymethane. Cancer Lett 140: 99-104, 1999.

20. Paulsen JE, Loberg EM, Olstorn HB, Knutsen H, Steffensen IL and Alexander J: Flat dysplastic aberrant crypt foci are related to tumorigenesis in the colon of azoxymethane-treated rat. Cancer Res 65: 121-129, 2005.

21. Suzui M, Masuda M, Lim JTE, Albanese C, Pestell RG and Weinstein IB: Growth inhibition of human hepatoma cells by acyclic retinoid is associated with induction of p $21^{\mathrm{CIP} 1}$ and inhibition of expression of cyclin D1. Cancer Res 62: 3997-4006, 2002.

22. Shimizu M, Suzui M, Lim JTE and Weinstein IB: Effects of acyclic retinoid on growth, cell cycle control, the EGFR signaling pathway, and gene expression in human squamous cell carcinoma cell lines. Clin Cancer Res 10: 1130-1140, 2004. 
23. Suzui M, Shimizu M, Masuda M, Lim JTE, Yoshimi N and Weinstein IB: Acyclic retinoid activates retinoic acid receptor b and induces transcriptional activation of p21(CIP1) in HepG2 human hepatoma cells. Mol Cancer Ther 3: 309-316, 2004.

24. McWilliams RR and Erlichman C: Novel therapeutics in colorectal cancer. Dis Colon Rectum 48: 1632-1650, 2005.

25. Parkin DM: Global cancer statistics in the year 2000. Lancet Oncol 2: 533-543, 2001.

26. Parkin DM, Bray F, Ferlay J and Pisani P: Global cancer statistics, 2002. CA Cancer J Clin 55: 74-108, 2005.

27. Suzui M, Inamine M, Kaneshiro T, Morioka T, Yoshimi N, Suzuki R, Kohno H and Tanaka T: Indole-3-carbinol inhibits the growth of human colon carcinoma cells but enhances the tumor multiplicity and volume of azoxymethane-induced rat colon carcinogenesis. Int J Oncol 27: 1391-1399, 2005.

28. Matsumoto H, Erickson RH, Gum JR, Yoshioka M, Gum E and Kim YS: Biosynthesis of alkaline phosphatase during differentiation of the human colon cancer cell line Caco-2. Gastroenterology 98: 1199-1207, 1990.

29. Palmer HG, Gonzalez-Sancho JM, Espada J, Berciano MT, Puig I, Baulida J, Quintanilla M, Cano A, De Herreros AG, Lafarga M and Munoz A: Vitamin D(3) promotes the differentiation of colon carcinoma cells by the induction of E-cadherin and the inhibition of beta-catenin signaling. J Cell Biol 154: 369-387, 2001.

30. Nakamura N, Shidoji Y, Yamada Y, Hatakeyama H, Moriwaki H and Muto Y: Induction of apoptosis by acyclic retinoid in the human hepatoma-derived cell line, Huh-7. Biochem Biophys Res Commun 207: 382-388, 1995.

31. Muto Y and Moriwaki H: Antitumor activity of vitamin A and its derivatives. J Natl Cancer Inst 73: 1389-1393, 1984.
32. Um SJ, Kwon YJ, Han HS, Park SH, Park MS, Rho YS and Sin HS: Synthesis and biological activity of novel retinamide and retinoate derivatives. Chem Pharm Bull 52: 501-506, 2004.

33. Um SJ, Han HS, Kwon YJ, Park SH, Rho YS, Sin HS and Park JS: Novel retinoic acid derivative ABPN has potent inhibitory activity on cell growth and apoptosis in cancer cells. Int J Cancer 107: 1038-1046, 2003.

34. Landers JE, Cassel SL and George DL: Translational enhancement of $\mathrm{mdm} 2$ oncogene expression in human tumor cells containing a stabilized wild-type p53 protein. Cancer Res 57: 3562-3568, 1997.

35. Steinman RA, Hofmann B, Iro A, Guillouf C, Liebermann DA and El-Houseini M: Induction of p21 (WAF1/CIP1) during differentiation. Oncogene 9: 3389-3396, 1994.

36. Jiang H, Lin J, Su ZZ, Collart FR, Huberman E and Fisher PB: Induction of differentiation in human promyelocytic HL-60 leukemia cells activates p21, WAF1/CIP1, expression in the absence of p53. Oncogene 9: 3397-3406, 1994.

37. Hong WK and Sporn MB: Recent advances in chemoprevention of cancer. Science 278: 1073-1077, 1997.

38. Shao RX, Otsuka M, Kato N, Taniguchi H, Hoshida Y, Moriyama M, Kawabe T and Omata M: Acyclic retinoid inhibits human hepatoma cell growth by suppressing fibroblast growth factor-mediated signaling pathways. Gastroenterology 128 : $86-95,2005$

39. Wong N, Chan KY, Macgregor PF, Lai PB, Squire JA, Beheshti B, Albert $\mathrm{M}$ and Leung TW: Transcriptional profiling identifies gene expression changes associated with IFN- $\alpha$ tolerance in hepatitis C-related hepatocellular carcinoma cells. Clin Cancer Res 11: 1319-1326, 2005 